\title{
Paideusis
}

\section{Researching Lived Experiences: Human Science for an Action Sensitive Pedagogy (Max Van Manen)}

\section{Barrie R. C. Barrell}

Volume 7, Number 1, 1993

URI: https://id.erudit.org/iderudit/1073288ar

DOI: https://doi.org/10.7202/1073288ar

See table of contents

Publisher(s)

Canadian Philosophy of Education Society

ISSN

0838-4517 (print)

1916-0348 (digital)

Explore this journal

Cite this review

Barrell, B. (1993). Review of [Researching Lived Experiences: Human Science for an Action Sensitive Pedagogy (Max Van Manen)]. Paideusis, 7(1), 47-49.

https://doi.org/10.7202/1073288ar viewed online.

https://apropos.erudit.org/en/users/policy-on-use/ 


\section{Book Review}

Max Van Manen. Researching Lived Experiences: Human Science for an Action Sensitive Pedagogy. Albany, N.Y.: State University of New York Press, 1990.

The past decade in education has seen quantitative analysis give way to qualitative inquiry, behaviouristic studies give ground to reflective practice, and empirical studies superseded by story and anecdote, narrative inquiry and contemplative practice. Researchers have begun to look beyond the surface significance of what has been observed in overt classroom actions and behaviours, and are focusing more on the underlying structures of their practice and pedagogy. A researcher's relationship to the inner qualities and dynamics of the work has become the subject of inquiry. By putting aside quantitative analysis and technical conceptions of teaching, researchers are now moving toward conceptions that see practice more as a calling, a form of coaching or acting, a craft, or possibly as a form of artistic expression.

In Researching Lived Experiences: Human Science for an Action Sensitive Pedagogy, Max van Manen gives students new to qualitative research, as well as those who are struggling with its various forms, a methodology for undertaking and transcribing their lived pedagogical inquires. He leads the reader through the concerns that are relevant to participatory observational research and demonstrates the importance and care required of those who wish to development an insightful and thoughtful text about those experiences.

Chapter One "engages the reader in a pedagogic reflection on how we live with children as parents, teachers, or educators" (p. 1), and shows how one can employ the methods of phenomenology (the descriptions of events) and hermeneutics (the interpretation of events) to engage in qualitative research and begin to translate those experiences into a rich, vibrant language. Van Manen states that a semiotic or language orientation approach allows for the process "of textual reflection to contribute to one's pedagogic thoughtfulness and tact" (p. 2), and that hermeneutic phenomenology, in particular, offers a way of making interpretive sense of the phenomena of our living with children. Van Manen explores the researcher's personal involvement in both the research and in the development of a written text.

Chapter Two investigates the nature of lived experiences and how we can orient ourselves to phenomena in our efforts to abstract the essence from events. Van Manen tries to demystify the meaning of "essence" by explaining that it is a linguistic construction of a phenomenon that would allow for the grasping of the nature and significance of a pedagogical experience in "a hitherto unseen way" (p. 39). Therefore, we come to know the essence of something by constructing a description "that is both holistic and analytical, evocative and precise, unique and universal, powerful and sensitive" (p. 39). We are shown that the textual description needs to weave together both the factual and the ontological aspects of lived experiences. Interestingly, van Manen observes that "it is not that we know too little about the phenomenon we wish to investigate, but that we know too much" (p. 46). Using the concept of parenting, he argues that despite the endless studies about the subject, few ask questions about the "nature of parenting" (p. 48) in such a way as to reveal a sense of it as seen 
through the love given, the care shown, the behaviour exhibited, or the emotion expressed towards the child.

The next two chapters ("Investigating Experience As We Live It" and "Hermeneutic Phenomenological Reflection") develop the basis of his argument for the most important and the most significant section of van Manen's work-hermeneutic phenomenological writing. By simply showing the underlying importance of the researcher's written text and the intricate process of its construction, van Manen performs his greatest service. This is the chapter to which graduate students will retum often for ideas and for confirmation of their qualitative inquiries. Van Manen shows the importance of getting the language correct and our need to express as precisely as possible the nuance of a lived experience. Key to any qualitative research is the investigator's ability to look for meaning in lived experiences and then to express those findings and observations in clear, cogent, insightful prose. We are advised (pp. 8, 32, and 132) that it is only through the working and reworking of the written texts that our reflective theorising begins to take shape and form. Because data never speaks for itself, van Manen has us pay strict attention to the tonality and the subtlety of the words we select to express lived pedagogic experiences. He focuses our attention on the fact that human science research is, indeed, a form of writing. "Creating a phenomenological text is the object of the research process" that has as its fundamental aim the sensitive animation of "the research question" (p. 111). Thus, as pedagogic experiences are brought into symbolic form, we are made aware of "the undertones of language, to the way language speaks when it allows things themselves to speak" (p. 111). This emphasis on the quality of the developing written text is the underlying strength of van Manen's work. It is his ability to demonstrate the very importance of working and reworking our written prose to get the language "right" or to get the details of a pedagogic situation vibrant, clearly explained. It is here that van Manen's work at its best; it is rich and exemplary. We are urged to demand more than mere narcissistic recollections of pedagogic experiences.

Van Manen has explained why some qualitative research simply "rings true" and seems "right on the mark." It is the care shown in the recording and explaining of pedagogical events that we quickly recognise and appreciate in qualitative research. Indeed, the time and attention he gives to writing reminded me of the care Thoreau gave to the writing of Walden, or Life in Woods. It is sometimes forgotten that Thoreau waited five years before writing about the events experienced at Walden and in the surrounding woodlands. Thoreau teaches us to deliberate carefully and that reflection needs time and distance before the sublime or the poetic can be extracted from the depths of an event.

Logically, then, the writer must be a keen observer and a good listener, one who can discover themes, see essences, integrate observations, and describe things in ways that speak to us about the lifeworld of the phenomenon. Through such sensitive writing and rewriting of pedagogic experiences, van Manen insists that we are writing and building theory "not in a narcissistic sense but in a deep collective sense"' (p. 132).

In Chapter Six, the pitfalls and problems surrounding educational research are stressed. Van Manen warns that some "trendy ethnographic research" has produced 
Many studies of children's lives (and of the educators who figure significantly in their lives): children in classrooms, on play-grounds, in their neighbourhoods, adolescents in shopping malls. . . But what we are offered on the basis of these studies are texts of the lives of children, teachers, administrators, and so forth, that distance and estrange us from those lives rather than bring. . [these lives] closer into the field of vision of our interest in children as teachers, parents, educational administrators, and so on (pp. 135-136).

Van Manen warns that the child's experiences are often distanced or abstracted rather than brought into the written text. He urges us to act pedagogically upon our understandings even if pedagogy itself is seen to be "ineffable" (p. 143). He wishes researchers to go after the elusive-the intangible-nature of our lived experiences with children and subsequently offers suggestions on how this might be done in order that "a more hermeneutic type of competence" will evolve (p. 143). But the question for van Manen to explain is that, if pedagogy is ineffable, as he says, then how valid or applicable are the claims one can make about it? Would the concept of validity necessarily be inherent in the integrity and coherence of the researcher's constructed text? I believe so. Such an interpretive validity, however, would require a consensus upon a community of terms and conditions. Perhaps van Manen needs to clarify this issue.

As was stated earlier, for those who are beginning descriptive qualitative research, or who are trying to develop a qualitative research question, or who are simply struggling with the form itself, Researching Lived Experiences offers a very readable, thoughtful, and sensitive exploration of the issues surrounding hermeneutic and phenomenological inquiry. With the increasing exploration of qualitative issues in education, van Manen's work is highly recommended both as a resource book and as a graduate class text. Its clarity about issues relevant to the writing and construction of qualitative texts is unsurpassed.

Reviewed by Barrie R. C. Barrelh Memorial University 